\title{
Effect of Different Levels of Nitrogenous Fertilizer on Quality and Economics of Guava (Psidium guajava L.) Var. Sardar
}

\author{
D. L. Chavan*, B. R. Haral and A. S. Kadam \\ Department of Horticulture, College of Agriculture, Latur, India \\ Vasantrao Naik Marathwada Krishi Vidyapeeth, Parbhani-431402, M. S., India \\ *Corresponding author
}

\section{A B S T R A C T}

\section{Keywords}

Guava, fertilizers, urea, Quality, TSS, Ascorbic acid

\section{Article Info}

\section{Accepted:}

18 March 2021

Available Online:

10 April 2021
An experiment on effect of different levels of nitrogenous fertilizers on quality and economics of guava was carried out during kharif season-2014 at Instructional-CumResearch Farm, Department of Horticulture, College of Agriculture, Latur. Regarding the fruit quality characters like fruit length $(8.13 \mathrm{~cm})$, width $(7.70 \mathrm{~cm})$, weight of pulp (211.33 g), pulp: seed ratio (37.27) and chemical quality attributes like TSS (14.40 ${ }^{0}$ Brix), reducing and total sugars (5.29 and $8.21 \%$ respectively) and minimum value of acidity $(0.36 \%)$ were recorded in treatment of application $800 \mathrm{~g} \mathrm{~N}$ through neem coated urea $\left(\mathrm{T}_{2}\right)$. While, post harvest qualities in terms of maximum shelf life (7.63 days) and minimum weight loss after 8 days storage (14.55\%) was recorded in guava fruits produced from the treatment of application of $600 \mathrm{~g} \mathrm{~N}$ through neem coated urea $\left(\mathrm{T}_{1}\right)$. Maximum ascorbic acid content $(187.13 \mathrm{mg} / 100 \mathrm{~g}$ pulp) was recorded with the application of $1000 \mathrm{~g} \mathrm{~N}$ through neem coated urea $\left(\mathrm{T}_{3}\right)$. The economics of guava production, under the influence of different treatments showed that, the highest cost of cultivation (Rs. 1,67,078.66/ha) was recorded with the application of $800 \mathrm{~g} \mathrm{~N}$ through ammonium sulphate $\left(\mathrm{T}_{5}\right)$. The highest gross and net monetary returns (Rs. 3,73,200 and Rs. 2,08,002 respectively) as well as the benefit: cost ratio (2.25) was observed with the application of $800 \mathrm{~g} \mathrm{~N}$ through neem coated urea $\left(\mathrm{T}_{2}\right)$.

\section{Introduction}

Guava (Psidium guajava L.) is one of the most important fruit crops of tropical and subtropical regions of India. It can be grown satisfactorily on marginal soils with minimum care and is aptly called as 'Apple of the Tropics'. It is the most important member of the Myrtaceae family. Guava is classified under genus Psidium, which consists of 150 species (Hayes, 1970) but only Psidium guajava has been exploited commercially. It has paramount importance as source of ascorbic acid in human diet, content of which is three to five times more than that in fresh orange juice. It is a very rich source of vitamin $\mathrm{C}$ and $\mathrm{A}$ along with minerals like iron, calcium and phosphorous. It also contains 
substantial quantities of carbohydrates, sugars and pectin. Owing to excellent taste and flavor, high nutritional value and wide availability at moderate price the fruit is often called as "Poor man's apple". The conventional products of guava are jelly, jam, pulp, concentrate, juice, cheese, toffee, dehydrated guava and canned guava. The physico-chemical characteristics of guava vary with varieties, stages of maturity, management practices, agro-climatic situations, season of the crop, etc. The ripe fruit contain approximately 79.50 per cent moisture, 15.25 per cent dry matter, 3.20 per cent crude fibre and little amount of ash. The TSS varies from 10.5-14.5 per cent. Several volatile compounds including hydrocarbons, alcohol and carbonyls have been found to be responsible for the characteristic flavor of guava. The decrease in astringency with advancement of maturity is ascribed to polymerization of leuco-anthocyanins.

\section{Materials and Methods}

The present investigation entitled "Effect of different levels of nitrogenous fertilizers on quality and economics of guava (Psidium guajava L.) var. Sardar." was carried out during 2014 at the Instructional -Cum Research Farm, Department of Horticulture, and College of Agriculture. Latur. The experiment was laid out in Randomized Block Design (RBD) with ten treatments of different nitrogenous fertilizers comprises $600 \mathrm{~g} \mathrm{~N}$ through Neem coated Urea/ Tree $\left(\mathrm{T}_{1}\right) .800 \mathrm{~g} \mathrm{~N}$ through Neem coated urea/ Tree $\left(\mathrm{T}_{2}\right) .1000 \mathrm{~g}$ $\mathrm{N}$ through Neem coated urea/ Tree $\left(\mathrm{T}_{3}\right), 600 \mathrm{~g}$ $\mathrm{N}$ through Ammonium Sulphate / Tree $\left(\mathrm{T}_{4}\right)$. $800 \mathrm{~g} \mathrm{~N}$ through Ammonium Sulphate / Tree $\left(\mathrm{T}_{5}\right), 1000 \mathrm{~g} \mathrm{~N}$ through Ammonium Sulphate / Tree $\left(\mathrm{T}_{6}\right) .600 \mathrm{~g} \mathrm{~N}$ through Granulated urea / tree $\left(\mathrm{T}_{7}\right), 800 \mathrm{~g} \mathrm{~N}$ through Granulated urea / tree $\left(\mathrm{T}_{8}\right) .1000 \mathrm{~g} \mathrm{~N}$ through Granulated urea / tree $\left(\mathrm{T}_{9}\right), 800 \mathrm{~g} \mathrm{~N}$ through urea / tree (Control) $\left(\mathrm{T}_{10}\right)$ replicated thrice. The periodical observation on quality parameters were recorded. The find data of each characters recorded during the investigation were analyzed statistically by various treatment was judge as suggested by Panse and Sukhatme (1985).

\section{Results and Discussion}

The data in relation to different physical quality aspects of fruits like length of fruit, width of fruit, weight of pulp, weight of seed and pulp: seed ratio are presented in Table -1 .

The data clearly showed that, produced maximum fruit length $(8.13 \mathrm{~cm})$, maximum width of the fruit $(7.70 \mathrm{~cm})$, maximum weight of pulp (211.33 g) and maximum pulp: seed ratio (37.27) was observed in the treatment of $800 \mathrm{~g} \mathrm{~N}$ application through neem coated urea $\left(\mathrm{T}_{2}\right)$.

The minimum weight of seeds $(5.17 \mathrm{~g})$ per fruit was recorded in the treatment of $600 \mathrm{~g} \mathrm{~N}$ application through neem coated urea $\left(\mathrm{T}_{1}\right)$.

Quality improvement in the treatment of neem coated urea may be due to the result of better vegetative growth of the treated plants which resulted in production of higher quantities of photosynthesis such as starch and carbohydrates and their translocation to the fruits, thus increasing the length, width and weight of fruits. The quality improvement in terms of physical attributes of fruits with the application of $600 \mathrm{~g} \mathrm{~N}$ through neem coated urea has also been reported by Ram et al., (1999). Neem coated urea acts as nitrogen inhibitor and results in reduced loss of nutrients from soil.

The maximum TSS (14.40 ${ }^{0}$ Brix $)$ was observed in the fruits produced with the application of $800 \mathrm{~g} \mathrm{~N}$ through neem coated urea $\left(\mathrm{T}_{2}\right)$, maximum reducing sugars $(5.29 \%)$, total sugars $(8.21 \%)$ and maximum ascorbic 
acid content (187.13 mg/100g pulp) was observed in the treatment of $1000 \mathrm{~g} \mathrm{~N}$ application through neem coated urea $\left(\mathrm{T}_{3}\right)$. The fruit quality in terms of TSS, ascorbic acid, reducing sugars and total sugars was significantly superior with high values of these parameters and minimum value of acidity in the treatment of $800 \mathrm{~g} \mathrm{~N}$ through neem coated urea $\left(\mathrm{T}_{2}\right)$.

The beneficial effects of such inorganic fertilizers have also been reported by Ram et al., (1999) and Kumar et al., (2010). The improvement in TSS, reducing sugars and total sugars of fruits may be due to the neem coated urea plays major role due to enhanced enzymatic activities during fruit maturity and ripening.

The carbohydrate reserves of the roots and stems are drawn upon heavily which might have resulted in higher sugar contents in fruits. These findings are in alignment with Muhammad et al., (2000). The increased in ascorbic acid contents of fruits were also observed due to the application of $\mathrm{N}$ through neem coated urea Ram et al., (1999).

The significant differences in respect of physiological loss in weight of fruits were observed among the different treatments at different storage period.

At $2^{\text {nd }}, 4^{\text {th }}, 6^{\text {th }}$ and $8^{\text {th }}$ days of storage, minimum per cent weight loss of fruits (3.09, $5.67,9.22$ and $14.55 \%$ respectively) was recorded in the fruits produced with the application of $600 \mathrm{~g} \mathrm{~N}$ through neem coated urea $\left(\mathrm{T}_{1}\right)$.

The maximum per cent weight loss (5.94, $9.60,14.70$ and 21.38 respectively) was observed in the fruits obtained from the treatment of $1000 \mathrm{~g} \mathrm{~N}$ application through granulated urea $\left(T_{9}\right)$. However, minimum weight loss and more shelf life in the fruits of
$600 \mathrm{~g} \mathrm{~N}$ application through neem coated urea $\left(\mathrm{T}_{1}\right)$, treatment could be attributed to slower rate of respiration and reduced enzymatic activities and slower biochemical changes occurring in the fruits of this treatment. Dhomane and Kadam (2013) reported that, fruit produced from the trees receiving $75 \% \mathrm{~N}$ through urea and $25 \% \mathrm{~N}$ through neem cake showed minimum physiological loss in weight $(12.06 \%)$ after 8 days of storage and, maximum shelf life of guava fruits (7.4 days) was observed in the fruits produced from the trees receiving $100 \% \mathrm{~N}$ through organic manures.

The lowest cost of cultivation (Rs. $1,56,664.66 / \mathrm{ha})$ was observed in control $\left(\mathrm{T}_{10}\right)$ treatment, while the highest cost of cultivation (Rs. 1,67,078.66/ha) was observed in the treatment of application of $800 \mathrm{~g} \mathrm{~N}$ through ammonium sulphate $\left(T_{5}\right)$, the highest gross and net monetary returns per hectare (Rs. 3, 73,200 and Rs. 2,08,002) were obtained in the treatment of application of $800 \mathrm{~g} \mathrm{~N}$ through neem coated urea $\left(\mathrm{T}_{2}\right)$.

The highest percent increase in net profit (25.80) was recorded in the treatment of $800 \mathrm{~g}$ $\mathrm{N}$ application through neem coated urea $\left(\mathrm{T}_{2}\right)$ while, the lowest percent increase in net profit (0.99) was recorded in $\left(\mathrm{T}_{7}\right)$ treatment of application of $600 \mathrm{~g} \mathrm{~N}$ through granulated urea and highest benefit: cost ratio (2.25) was recorded in the treatment of $800 \mathrm{~g} \mathrm{~N}$ application through neem coated urea $\left(\mathrm{T}_{2}\right)$ while, the lowest benefit: cost ratio (2.04) was recorded in control $\left(\mathrm{T}_{10}\right)$ treatment.

The maximum percent increase in net profit $(25.80 \%)$ occur in treatment of application of $800 \mathrm{~g} \mathrm{~N}$ through neem coated urea was recorded $\left(\mathrm{T}_{2}\right)$. Dhomane and Kadam (2013) obtained higher benefit: cost ratio due to application of $75 \% \mathrm{~N}$ through urea $+25 \% \mathrm{~N}$ through neem cake, which supports the present findings. 
The maximum values of physical quality character like fruit length $(8.13 \mathrm{~cm})$, width $(7.70 \mathrm{~cm})$, weight of pulp $(211.33 \mathrm{~g})$, pulp: seed ratio (37.27) and chemical quality attributes like TSS (14.40 ${ }^{0}$ Brix $)$, reducing and total sugars (5.29 and $8.21 \%$ respectively), minimum value of acidity $(0.36 \%)$ and maximum quality rating score (23.27 out of $25)$ were recorded in treatment of application $800 \mathrm{~g} \mathrm{~N}$ through neem coated urea $\left(\mathrm{T}_{2}\right)$ and Maximum ascorbic acid content (187.13 $\mathrm{mg} / 100 \mathrm{~g}$ pulp) was recorded with the application of $1000 \mathrm{~g} \mathrm{~N}$ through neem coated urea $\left(\mathrm{T}_{3}\right)$.

The lowest cost of cultivation (Rs. 1, $56,664.66 / \mathrm{ha})$ was required in control $\left(\mathrm{T}_{10}\right)$ treatment while, it was highest (Rs. 1, 67,078.66/ha) with the application of $800 \mathrm{~g} \mathrm{~N}$ through ammonium sulphate $\left(\mathrm{T}_{5}\right)$. The highest gross and net monetary returns (Rs. 3, 73,200 and Rs. 2,08,002 respectively) as well as the benefit: cost ratio (2.25) was observed with the application of $800 \mathrm{~g} \mathrm{~N}$ through neem coated urea $\left(\mathrm{T}_{2}\right)$.

Table.1 Effect of levels of different nitrogenous fertilizers on physical attributes of Sardar guava fruits.

\begin{tabular}{|c|c|c|c|c|c|c|}
\hline Tr. No. & Treatments & $\begin{array}{c}\text { Fruit } \\
\text { length } \\
(\mathrm{cm})\end{array}$ & $\begin{array}{c}\text { Fruit } \\
\text { width } \\
\text { (cm) }\end{array}$ & $\begin{array}{l}\text { Weigh } \\
\text { t of } \\
\text { pulp } \\
\text { (g) }\end{array}$ & $\begin{array}{l}\text { Weight } \\
\text { of } \\
\text { seeds/fr } \\
\text { uit } \\
\text { (g) }\end{array}$ & $\begin{array}{c}\text { Pulp : } \\
\text { Seed } \\
\text { ratio }\end{array}$ \\
\hline $\mathbf{T}_{1}$ & $600 \mathrm{~g} \mathrm{~N}$ through Neem coated urea/ tree. & 7.73 & 7.16 & 187.23 & 5.17 & 36.46 \\
\hline $\mathbf{T}_{2}$ & $800 \mathrm{~g} \mathrm{~N}$ through Neem coated urea/ tree. & 8.13 & 7.70 & 211.33 & 5.67 & 37.27 \\
\hline $\mathbf{T}_{\mathbf{3}}$ & $1000 \mathrm{~g} \mathrm{~N}$ through Neem coated urea/ tree. & 7.88 & 7.58 & 203.20 & 7.27 & 27.95 \\
\hline $\mathbf{T}_{4}$ & $\begin{array}{c}600 \mathrm{~g} \mathrm{~N} \text { through Ammonium sulphate/ } \\
\text { tree }\end{array}$ & 7.46 & 6.83 & 197.87 & 6.50 & 30.44 \\
\hline $\mathbf{T}_{5}$ & $\begin{array}{c}800 \mathrm{~g} \mathrm{~N} \text { through Ammonium sulphate/ } \\
\text { tree. }\end{array}$ & 7.77 & 6.95 & 209.80 & 6.57 & 31.93 \\
\hline $\mathbf{T}_{6}$ & $\begin{array}{c}1000 \mathrm{~g} \mathrm{~N} \text { through Ammonium sulphate/ } \\
\text { tree. }\end{array}$ & 7.65 & 7.07 & 192.73 & 7.57 & 25.45 \\
\hline $\mathbf{T}_{7}$ & $600 \mathrm{~g} N$ through Granulated urea/ tree. & 7.33 & 6.65 & 196.47 & 6.80 & 28.89 \\
\hline $\mathbf{T}_{8}$ & $800 \mathrm{~g} \mathrm{~N}$ through Granulated urea/ tree. & 7.73 & 7.02 & 207.47 & 6.67 & 31.10 \\
\hline $\mathbf{T}_{9}$ & $1000 \mathrm{~g} \mathrm{~N}$ through Granulated urea/ tree. & 7.52 & 6.91 & 198.13 & 6.87 & 28.83 \\
\hline $\mathbf{T}_{10}$ & $800 \mathrm{~g} \mathrm{~N}$ through urea/ tree. (Control). & 6.97 & 6.48 & 169.10 & 8.17 & 20.69 \\
\hline S.E. \pm & & 0.17 & 0.23 & 3.77 & 0.58 & 2.41 \\
\hline $\begin{array}{c}\text { C.D at } \\
5 \%\end{array}$ & & 0.52 & 0.68 & 11.20 & 1.75 & 7.16 \\
\hline
\end{tabular}


Table.2 Effect of levels of different nitrogenous fertilizers on chemical composition of Sardar guava fruits.

\begin{tabular}{|c|c|c|c|c|c|c|}
\hline $\begin{array}{l}\text { Tr. } \\
\text { No. }\end{array}$ & Treatments & $\begin{array}{c}\text { Total Soluble } \\
\text { Solids } \\
\left.\text { ( }{ }^{0} \text { Brix }\right)\end{array}$ & $\begin{array}{c}\text { Ascorbic acid } \\
\text { (mg/100g fruit } \\
\text { pulp) }\end{array}$ & $\begin{array}{l}\text { Reducing } \\
\text { sugar } \\
(\%)\end{array}$ & $\begin{array}{c}\text { Total } \\
\text { sugars } \\
(\%)\end{array}$ & $\begin{array}{c}\text { Acidity } \\
(\%)\end{array}$ \\
\hline $\mathbf{T}_{1}$ & $600 \mathrm{~g} \mathrm{~N}$ through Neem coated urea/ tree. & 13.40 & 162.23 & 4.72 & 7.67 & 0.37 \\
\hline $\mathbf{T}_{2}$ & $800 \mathrm{~g} \mathrm{~N}$ through Neem coated urea/ tree. & 14.40 & 181.33 & 5.29 & 8.21 & 0.36 \\
\hline $\mathbf{T}_{3}$ & $1000 \mathrm{~g} \mathrm{~N}$ through Neem coated urea/ tree. & 13.50 & 187.13 & 5.24 & 7.83 & 0.53 \\
\hline $\mathbf{T}_{4}$ & $600 \mathrm{~g} \mathrm{~N}$ through Ammonium sulphate/ tree & 13.27 & 179.33 & 5.09 & 7.92 & 0.38 \\
\hline $\mathbf{T}_{5}$ & $800 \mathrm{~g} \mathrm{~N}$ through Ammonium sulphate/ tree. & 14.13 & 161.23 & 4.78 & 7.60 & 0.40 \\
\hline $\mathbf{T}_{6}$ & $1000 \mathrm{~g} \mathrm{~N}$ through Ammonium sulphate/ tree. & 13.47 & 165.93 & 4.50 & 7.37 & 0.55 \\
\hline $\mathbf{T}_{7}$ & $600 \mathrm{~g} \mathrm{~N}$ through Granulated urea/ tree. & 12.57 & 162.93 & 4.81 & 7.77 & 0.50 \\
\hline $\mathbf{T}_{8}$ & $800 \mathrm{~g} \mathrm{~N}$ through Granulated urea/ tree. & 13.00 & 168.17 & 4.89 & 7.71 & 0.53 \\
\hline $\mathbf{T}_{9}$ & $1000 \mathrm{~g} \mathrm{~N}$ through Granulated urea/ tree. & 13.17 & 168.70 & 4.86 & 7.69 & 0.59 \\
\hline $\mathbf{T}_{10}$ & $800 \mathrm{~g} \mathrm{~N}$ through urea/ tree. (Control). & 12.17 & 160.33 & 4.90 & 7.90 & 0.48 \\
\hline S.E. \pm & & 0.31 & 3.11 & 0.14 & 0.11 & 0.01 \\
\hline $\begin{array}{c}\text { C.D } \\
\text { at } \\
5 \%\end{array}$ & & 0.92 & 9.26 & 0.42 & 0.35 & 0.03 \\
\hline
\end{tabular}

Table.3 Effect of levels of different nitrogenous fertilizers on post harvest qualities and shelf life of Sardar guava fruits.

\begin{tabular}{|c|c|c|c|c|c|c|}
\hline \multirow{2}{*}{$\begin{array}{l}\text { Tr. } \\
\text { No. }\end{array}$} & \multirow{2}{*}{ Treatments } & \multirow{2}{*}{$\begin{array}{c}\text { Initial } \\
\text { weight }(g)\end{array}$} & \multicolumn{4}{|c|}{ Physiological loss in weight $(\%)$} \\
\hline & & & After 2 days & After 4 days & After 6 days & After 8 days \\
\hline $\mathbf{T}_{1}$ & $600 \mathrm{~g} \mathrm{~N}$ through Neem coated urea/ tree. & 1003.00 & $\begin{array}{c}3.09 \\
(972.00)\end{array}$ & $\begin{array}{c}5.67 \\
(946.12)\end{array}$ & $\begin{array}{c}9.22 \\
(910.52)\end{array}$ & $\begin{array}{c}14.55 \\
(857.06)\end{array}$ \\
\hline $\mathbf{T}_{2}$ & $800 \mathrm{~g} \mathrm{~N}$ through Neem coated urea/ tree. & 1269.30 & $\begin{array}{c}3.33 \\
(1227.03)\end{array}$ & $\begin{array}{c}6.77 \\
(1183.36)\end{array}$ & $\begin{array}{c}11.96 \\
(1117.49)\end{array}$ & $\begin{array}{c}15.14 \\
(1077.12)\end{array}$ \\
\hline $\mathbf{T}_{3}$ & $1000 \mathrm{~g} \mathrm{~N}$ through Neem coated urea/ tree. & 1209.12 & $\begin{array}{c}3.49 \\
(1167.74)\end{array}$ & $\begin{array}{c}6.04 \\
(1135.97)\end{array}$ & $\begin{array}{c}10.73 \\
(1079.27)\end{array}$ & $\begin{array}{c}16.11 \\
(1014.33)\end{array}$ \\
\hline $\mathbf{T}_{4}$ & $600 \mathrm{~g} \mathrm{~N}$ through Ammonium sulphate/ tree & 952.00 & $\begin{array}{c}4.04 \\
(913.53)\end{array}$ & $\begin{array}{c}6.20 \\
(892.97)\end{array}$ & $\begin{array}{c}12.09 \\
(829.19)\end{array}$ & $\begin{array}{c}15.77 \\
(801.86)\end{array}$ \\
\hline $\mathbf{T}_{5}$ & $800 \mathrm{~g} \mathrm{~N}$ through Ammonium sulphate/ tree. & 1001.10 & $\begin{array}{c}4.27 \\
(958.25)\end{array}$ & $\begin{array}{c}6.22 \\
(938.73)\end{array}$ & $\begin{array}{c}10.04 \\
(900.49)\end{array}$ & $\begin{array}{c}16.30 \\
(837.92)\end{array}$ \\
\hline $\mathbf{T}_{6}$ & $1000 \mathrm{~g} \mathrm{~N}$ through Ammonium sulphate/ tree. & 1028.90 & $\begin{array}{c}5.92 \\
(937.97)\end{array}$ & $\begin{array}{c}9.41 \\
(932.08)\end{array}$ & $\begin{array}{c}13.33 \\
(891.74)\end{array}$ & $\begin{array}{c}17.02 \\
(853.78)\end{array}$ \\
\hline $\mathbf{T}_{7}$ & $600 \mathrm{~g} \mathrm{~N}$ through Granulated urea/ tree. & 951.00 & $\begin{array}{c}5.67 \\
(897.07)\end{array}$ & $\begin{array}{c}7.67 \\
(878.05)\end{array}$ & $\begin{array}{c}11.04 \\
(846.00)\end{array}$ & $\begin{array}{c}16.41 \\
(794.94)\end{array}$ \\
\hline $\mathbf{T}_{8}$ & $800 \mathrm{~g} \mathrm{~N}$ through Granulated urea/ tree. & 1033.20 & $\begin{array}{c}4.39 \\
(987.84)\end{array}$ & $\begin{array}{c}7.33 \\
(957.26)\end{array}$ & $\begin{array}{c}12.89 \\
(900.02)\end{array}$ & $\begin{array}{c}18.26 \\
(844.53)\end{array}$ \\
\hline $\mathbf{T}_{9}$ & $1000 \mathrm{~g} \mathrm{~N}$ through Granulated urea/ tree. & 954.00 & $\begin{array}{c}5.94 \\
(897.33)\end{array}$ & $\begin{array}{c}9.60 \\
(862.41)\end{array}$ & $\begin{array}{c}14.70 \\
(813.76)\end{array}$ & $\begin{array}{c}21.38 \\
(750.03)\end{array}$ \\
\hline $\mathbf{T}_{10}$ & $800 \mathrm{~g} \mathrm{~N}$ through urea/ tree. (Control). & 686.50 & $\begin{array}{c}4.36 \\
(656.09)\end{array}$ & $\begin{array}{c}10.52 \\
(613.83)\end{array}$ & $\begin{array}{c}14.47 \\
(586.73)\end{array}$ & $\begin{array}{c}20.72 \\
(543.86)\end{array}$ \\
\hline S.E. \pm & & & 0.10 & 0.11 & 0.14 & 0.20 \\
\hline $\begin{array}{c}\text { C.D at } \\
5 \%\end{array}$ & & & 0.30 & 0.35 & 0.42 & 0.60 \\
\hline
\end{tabular}


Table.4 Effect of levels of different nitrogenous fertilizers on economics of Sardar guava production.

\begin{tabular}{|c|c|c|c|c|c|c|}
\hline $\begin{array}{l}\text { Tr. } \\
\text { No. }\end{array}$ & Treatments & $\begin{array}{c}\text { Cost of } \\
\text { cultivation } \\
\text { (Rs./ha) }\end{array}$ & $\begin{array}{c}\text { Gross } \\
\text { returns } \\
\text { (Rs./ha) }\end{array}$ & $\begin{array}{l}\text { Net } \\
\text { returns } \\
\text { (Rs./ha) }\end{array}$ & $\begin{array}{c}\text { Percent } \\
\text { increase } \\
\text { in net } \\
\text { profit }\end{array}$ & $\begin{array}{c}\text { Benefit : } \\
\text { Cost } \\
\text { ratio }\end{array}$ \\
\hline $\mathbf{T}_{1}$ & $\begin{array}{c}600 \mathrm{~g} \mathrm{~N} \text { through Neem coated } \\
\text { urea/ tree. }\end{array}$ & 160492.33 & 345800 & 185307.67 & 12.07 & 2.15 \\
\hline $\mathbf{T}_{2}$ & $\begin{array}{c}800 \mathrm{~g} \mathrm{~N} \text { through Neem coated } \\
\text { urea/ tree. }\end{array}$ & 165198.00 & 373200 & 208002.00 & 25.80 & 2.25 \\
\hline $\mathbf{T}_{\mathbf{3}}$ & $\begin{array}{l}1000 \mathrm{~g} \mathrm{~N} \text { through Neem } \\
\text { coated urea/ tree. }\end{array}$ & 162741.66 & 356800 & 194058.34 & 17.37 & 2.19 \\
\hline $\mathbf{T}_{4}$ & $\begin{array}{c}600 \mathrm{~g} \mathrm{~N} \text { through Ammonium } \\
\text { sulphate/ tree }\end{array}$ & 160427.66 & 330400 & 169972.33 & 2.80 & 2.05 \\
\hline $\mathbf{T}_{5}$ & $\begin{array}{c}800 \mathrm{~g} \mathrm{~N} \text { through Ammonium } \\
\text { sulphate/ tree. }\end{array}$ & 167078.66 & 362800 & 195721.33 & 18.37 & 2.17 \\
\hline $\mathbf{T}_{6}$ & $\begin{array}{c}1000 \mathrm{~g} \mathrm{~N} \text { through Ammonium } \\
\text { sulphate/ tree. }\end{array}$ & 166002.00 & 348000 & 181998.00 & 10.07 & 2.09 \\
\hline $\mathbf{T}_{7}$ & $\begin{array}{c}600 \mathrm{~g} \mathrm{~N} \text { through Granulated } \\
\text { urea/ tree. }\end{array}$ & 156825.66 & 323800 & 166974.33 & 00.99 & 2.06 \\
\hline $\mathbf{T}_{8}$ & $\begin{array}{c}800 \mathrm{~g} \mathrm{~N} \text { through Granulated } \\
\text { urea/ tree. }\end{array}$ & 160404.66 & 344800 & 184336.00 & 11.49 & 2.14 \\
\hline $\mathbf{T}_{9}$ & $\begin{array}{c}1000 \mathrm{~g} \mathrm{~N} \text { through Granulated } \\
\text { urea/ tree. }\end{array}$ & 159109.33 & 335000 & 175890.67 & 6.38 & 2.10 \\
\hline $\mathbf{T}_{10}$ & $\begin{array}{l}800 \mathrm{~g} \mathrm{~N} \text { through urea/ tree. } \\
\text { (Control). }\end{array}$ & 156664.66 & 322000 & 165335.33 & - & 2.04 \\
\hline
\end{tabular}

The significantly higher yield and better quality fruits with high $\mathrm{B}$ : $\mathrm{C}$ ratio was obtained with the nitrogen level of $800 \mathrm{~g}$ $\mathrm{N} /$ tree through different nitrogenous fertilizers tried. Hence, indicating there is no need to further increase of nitrogen dose for guava trees. Among different nitrogenous fertilizer nitrogen application through neem coated urea @ $800 \mathrm{~g} \mathrm{~N} /$ tree/year produced high yield $(67.13 \mathrm{~kg} /$ tree and $18.66 \mathrm{t} / \mathrm{ha})$, fruits of better quality with high (2.25) $\mathrm{B}$ : $\mathrm{C}$ ratio; besides improving the physical and chemical properties of soil.

\section{References}

A.O.A.C. 1975. Official methods of analysis. Association of official analytical chemists. $12^{\text {th }}$ edition, Washington D.C.

Anonymous. 2014. Indian Horticulture Database, National Horticulture Board, Government of India.

Anonymous. 2014. Krishi Dainandini, Marathwada Agricultural University, Parbhani: 152:153.

Dawoud, H.D., Fatima, O.A. and Ahmend, A.S. 1991. Effect of different rates of nitrogen fertilizers on growth, fruit quality and yield of guava under new Halfa conditions. Annual Report of New Halfa Research Station 1993/94ARC Sudan.

Dhomane, P.A. and Kadam, A.S. 2013. Effect of different sources of nitrogen on growth, yield and quality of 
guava (Psidium guajava L.) $\mathrm{Cv}$. Sardar. Scholarly Journal of Agricultural Science. 3(7): 261-263.

Kadam, A.S. and Patil, V.K. 1992. Influence of nutrient elements on growth of Sardar guava. J. Maharashtra agric. Univ., 17(1): 154-155.

Katiyar, P.N., Ning, J.P. and Sing, P.C.2008. Effect of nitrogen with and without zinc and organic manure on growth, yield and quality of guava (Psidium guajava L.) Cv. Sardar. Asian J. of Hort. 3(2):283-286

Kumar, R., Kotur, S.C. and Singh, H.P. 1995. Effect of different levels of phosphorus on, growth, fruit yield and quality of guava Cv. Allahabad Safeda under sub-humid conditions of Bihar. Indian J. Hort. 52(4): 254-258.

Kumar, R., Kotur, S.C. and Singh, H.P. 1996. Effect of nitrogen on growth, fruit yield and quality of guava under rainfed conditions of Bihar plateau.. Indian J. Hort. 53(2):109-113.

Panse, V.G. and Sukhatme, P.V. 1985. Statistical methods for agricultural workers, ICAR, New Delhi.

Ram, R.A., Rajput, M.S. and Bhriguvanshi, S.R. 1999. Effect of controlled-release fertilizers on growth, yield and fruit quality of guava Cv. Sardar in Ustochrepts.. Indian J. Hort. 56(2): 104-111.

Ram, R.A., and Rajput, M.S. and Shrivastava, R.B.L. 2006. Economic evaluation of guava $\mathrm{Cv}$. Sardar production with slow releasing nitrogenous along with phosphatic and potassic fertilizers. Int. J.of Mendel, 23: 25-29.

Sharma, S., Wali,V.K., Bakshi, P. and Jasrotiya. A. 2013. Effect of organic and inorganic fertilizers on quality and shelf life of guava (Psidium guajava L.) Cv. Sardar. The Boiscan, 8(4):1247-1250.

Sing, A.A. 2012. Effect of inorganic and biofertilizers on growth, yield and quality of Sardar guava (Psidium guajava L.) M.Sc. Thesis submitted to MKV, Parbhani.

Singh, G. 2009. Guava for socio-economic prosperity. Indian Hort., 54(4): 10-15.

Tassar, K., Tiwari, J.P. and Lal, S. 1989. Effect of different levels of Potassium on leaf nutrient status, fruit yield and quality of guava (Psidium guajava $\mathrm{L}$.) Cv. Sardar. Prog. Hort. 21(1-2): 51-55.

\section{How to cite this article:}

Chavan, D. L., B. R. Haral and Kadam, A. S. 2021. Effect of Different Levels of Nitrogenous Fertilizer on Quality and Economics of Guava (Psidium guajava L.) Var. Sardar. Int.J.Curr.Microbiol.App.Sci. 10(04): 696-702. doi: https://doi.org/10.20546/ijcmas.2021.1004.070 